\title{
Assessing the Applicability of Low Impact Development Techniques in Arid and Semi-arid Regions
}

\author{
Hadi Heidari $^{*{ }^{*}}$, Mohammad Reza Kavianpour ${ }^{2}$ \\ ${ }^{1}$ Department of Civil and Environmental Engineering, University of Massachusetts, Massachusetts, USA \\ ${ }^{2}$ Civil Engineering Department, K.N. Toosi University of Technology, Tehran, Iran \\ *E-mail: Hheidari@umass.edu
}

Received: 22 April 2021; Revised: 3 July 2021; Accepted: 7 August 2021

\begin{abstract}
Low impact development (LID) techniques are increasingly used as a stormwater management strategy to maintain the hydrological conditions of developed areas and mitigate the negative consequences of stormwater runoff and nonpoint source pollution. Although LID techniques have been commonly used in moderate to humid areas, further information is needed on their effectiveness in semi-arid and arid regions. This study aims to examine and compare the effectiveness of LID techniques in arid and semi-arid climate conditions. First, a comprehensive study was conducted to rank LID techniques based on literature reviews while also incorporating different stakeholder priorities. Then, the city of Varamin, Tehran, Iran, was chosen as a low slope arid and semi-arid study region to assess the applicability of the best three high-ranked LID techniques using the storm water management model (SWMM). The results indicated that rainwater harvesting is the most effective technique in terms of stormwater quality and quantity management. The implementation of the rainwater harvesting technique across the case study is likely to decrease the average discharge, peak discharge, total volume, total runoff, and total suspended solids (TSS) by respectively 31.2\%, 12.7\%, 40.71\%, $40.77 \%$ and $37.91 \%$. Besides, rainwater tanks were projected to provide the water demands of home gardens during the five dry months, in addition to other domestic needs for water conservation objectives. The application of LID techniques in such water-limited regions can be useful for both stormwater management and water conservation.
\end{abstract}

Keywords: low impact development, arid climate, rainwater harvesting, bioretention, permeable pavement, stormwater management

\section{Introduction}

Urbanization can transform natural and vegetated areas into urban landscapes that are dominated by impervious surfaces such as roofs, roads, driveways, parking lots, and sidewalks [1,2]. This transformation can lead to serious negative consequences on water and energy balances, such as increasing stormwater, urban heat island (UHI) [3,4], increasing water demand [5-7] and pressures on water resources [8-11]. However, efficient use of landscape resources can attenuate the negative effects of urban development $[6,12]$.

Heidari et al. [6] found that the high-density urban development pattern can decrease water use for outdoor irrigation and lead to water shortage conditions with lower intensity, duration, and frequency compared to the sprawling urban development pattern. However, previous studies have highlighted that urbanization under the high-density

Copyright (C2021 Hadi Heidari, et al.

DOI: https://doi.org/10.37256/epr.112021889

This is an open-access article distributed under a CC BY license

(Creative Commons Attribution 4.0 International License)

https://creativecommons.org/licenses/by/4.0/ 
development pattern may have negative consequences on other aspects of the urban water cycles, such as increase in stormwater due to more impervious areas $[13,14]$. Thus, an integrated water and land management strategy is needed to attenuate and mitigate negative consequences on society and the environment $[15,16]$.

Low impact development (LID) practices are known as stormwater management strategies that aim to preserve the natural functions and drainage systems of urban areas and reduce the negative effects of urbanization [17,18]. LID is an environmentally sustainable solution that considers stormwater as a water resource that should not be quickly transported or disposed $[1,19,20]$. LID practices are designed to mitigate some negative impacts of urbanization that conventional stormwater management techniques have not been able to appropriately address [18,19,21].

Most LID practices were first developed and applied in temperate regions where rainfall is abundant and few studies have focused on the effectiveness and applicability of LID practices in arid and semi-arid regions due to the perception that LID practices are useless in a region with little annual precipitation [2,14,22]. However, LID may be even more relevant in arid and semi-arid climates due to a more critical demand for water conservation $[2,23,24]$. Communities, researchers, and planners in the water-limited regions are increasingly recognizing LID as a cost-effective approach not only for stormwater management but also for water conservation [14,25].

Besides, the application of LIDs under arid conditions should be given even further attention because aridity can increase in response to climate change, land use change, and urbanization [11,26]. Climate change can lead to aridification due to increasing temperatures and shifting precipitation patterns $[27,28]$. The combination of climate change and rapid population growth can exacerbate the frequency of extreme events [10,29] and consequently lead to an increase in water shortage conditions and prolonged dry periods [10], particularly in urban areas. Thus, improved understanding of the effectiveness of LID techniques under arid climate conditions is necessary to enhance the resilience and sustainability of cities in response to climate change [15].

However, further research is needed to assess the applicability and effectiveness of LID techniques in arid and semi-arid climates $[2,17]$. Some believe that in arid environments, high irrigation may be required during prolonged dry periods after plants are established, and thus, the applicability of LID techniques is limited in such climates [30]. Therefore, special attention should be given to the selection and maintenance of LID techniques in arid and semi-arid regions [31].

Thus, the main goal of this study is to characterize appropriate LID techniques in low slope regions with arid and hot climate. Specifically, the objectives are to: 1) examine the positive and negative effects of LID techniques in arid regions; 2) characterize the most useful LID practices under arid climate conditions; and 3) assess changes in quantity and quality of stormwater by applying the high-ranked LID techniques to arid regions. Improved understanding of the key elements of LID in semi-arid and arid climate conditions provides insight for planners, designers, engineers, and stormwater managers to achieve stormwater management requirements [32].

\section{Background}

In 2010, a working group of experienced engineers was formed to evaluate and determine the appropriate LID technique in the Albuquerque area with an arid climate [33]. LID technique performance was ranked from highest to lowest. Averaged across the group, rain barrels/cisterns and green parking received the best ratings, while green/ living roofs came in last. While there was a general agreement on rain barrels/cisterns, there was little consensus on porous pavements. They reported that most participants thought cisterns/rain barrels, green parking, green streets, green detention facilities, swales, and flow-through planter boxes would perform well in the Albuquerque area. Many agreed that all techniques are feasible if used in the intended climate and for proper functions [33].

Ahiablame et al. [34] assessed the performance of rain barrel/cistern and porous pavement as retrofitting technologies in two urbanized watersheds near Indianapolis, Indiana, USA. Six scenarios consisting of the watershed's existing condition, $25 \%$ and $50 \%$ implementation of rain barrel/cistern and porous pavement, and $25 \%$ rain barrel/ cistern combined with $25 \%$ porous pavement were evaluated using a proposed LID modeling framework and the longterm hydrologic impact assessment (L-THIA) LID model. The various application levels of barrel/cistern and porous pavement resulted in a reduction in runoff and pollutant loads for the two watersheds. However, the reduction in runoff led to a reduction in total streamflow and associated pollutant loads in the watersheds. They also indicated that the 
combination of rain barrel/cistern and porous pavement is adequate for retrofitting options [34].

Amin et al. [35] in a study in Saudi Arabia, showed that an appropriate policy should be implemented to respond to the higher rain intensities of longer duration due to possible climatic change in the context of water management. Given the factors of climate change and population urban growth, rainwater harvesting could be a reasonable solution to water shortages in remote areas and flooding problems in urban areas [35].

El-Refaie et al. [36] studied the impact of arid climatic conditions on wetland design and performance in the Egypt basin. They reported that decreasing the wetland surface area and increasing the average flow rate cannot affect the removal efficiency of almost all pollutants. In addition, the study showed that the effect of temperature variation was pronounced in the increased removal efficiency of all studied parameters in the summer [36].

Jiang et al. [2] investigated the hydrological and environmental performance of nine field-scale LID practices in arid and semi-arid climates using cost-effectiveness analysis and recommended that rainwater harvesting systems, detention ponds, media filters, and vegetation buffers are applied in arid regions with caution due to nutrient export problems [2].

Bigurra-Alzati et al. [22] assessed the effectiveness of rainwater harvesting and green infrastructure to mitigate the water scarcity of Mineral de la Reforma, Mexico, as a residential region with a semi-arid climate. They figured out that the rainwater harvesting technique on rooftops and the runoff intercepted using green infrastructure can mitigate local water scarcity problems that are on the rise due to climate change [22]. Additionally, previous studies that evaluated the effectiveness of LID practices highlighted that excessive runoff generated by climate change can be mitigated by the implementation of LIDs [15].

\section{Methods}

In this section, we first explained the characteristics of the study area. The methodology for ranking the LID techniques in the arid region was illustrated and high-ranked techniques were selected. Then, the steps for developing and modeling the selected LID techniques using the storm water management model (SWMM) were provided. Finally, three scenarios were illustrated for examining the effectiveness of LID techniques in the arid climate.

\subsection{Study area}

Varamin city (latitude: 35.32 and longitude: 51.64 ) with an arid climate was selected to evaluate the effectiveness of LID techniques. This city is located 35 kilometers southeast of Tehran, the capital of Iran (Figure S1 in Appendix), and has an average elevation of 950 meters above sea level. The average rainfall is recorded at $131 \mathrm{~mm}$. Given the importance and value of water in this region from old times to now, conventional and historical water conservation systems such as Ab-Anbar (Figure S2 in Appendix) were applied in dry times. The application of water tanks for conservation purposes is common these days (Figure S3 in Appendix). When the pressure of the urban water supply network is high (during the night time), these tanks can be filled and consumed during the long days of water shortage crises.

The study area was selected in central Varamin City, which covers an area of approximately 201.6 hectares. The slope of the region is towards north-south and west-east. As shown in Figure 1, the study area is divided into three different subareas, which are north (n), central (c), and south (s). This division is based on the areal population density and land use for better evaluation of their impact on surface flow runoff. Table S1 in Appendix shows the percentage of land use in the subareas. Given that most office buildings are in the central area and the importance of these buildings in the application of rainwater harvesting tanks, the central area is considered separately from the northern area.

The Varamin climatology station was established in 2001. Therefore, there was only seven years of data available which was used for this study. Figure 2 shows the average daily rainfall distribution in the Varamin district. From Figure 2, the dry months (without precipitation) are June, July, August, September, and October.

Most logging problems in the current stormwater collection network occur in the southern area due to the conventional stormwater management approach that focused on collecting and conveying stormwater runoff in engineered systems (i.e. curb and gutter streets) as quickly as possible toward the drainage outlets in the downstream 
(Figure S4 in Appendix). This runoff control system decreases groundwater recharge, increases runoff volume, and changes the timing, frequency, and rate of discharge. These changes can cause flooding, water quality degradation, and stream erosion.

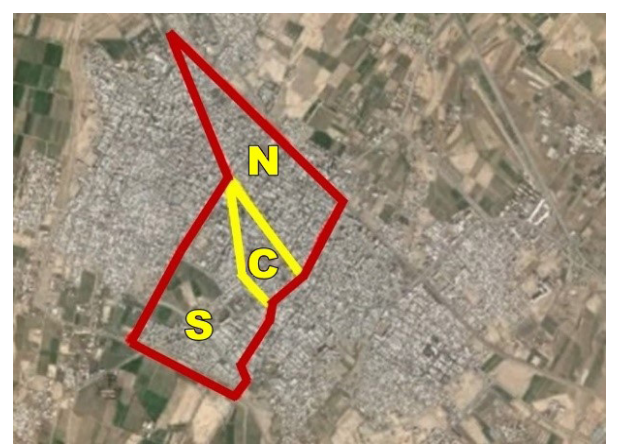

Figure 1. The study area is divided into north $(\mathrm{N})$, center $(\mathrm{C})$ and south $(\mathrm{S})$ regions

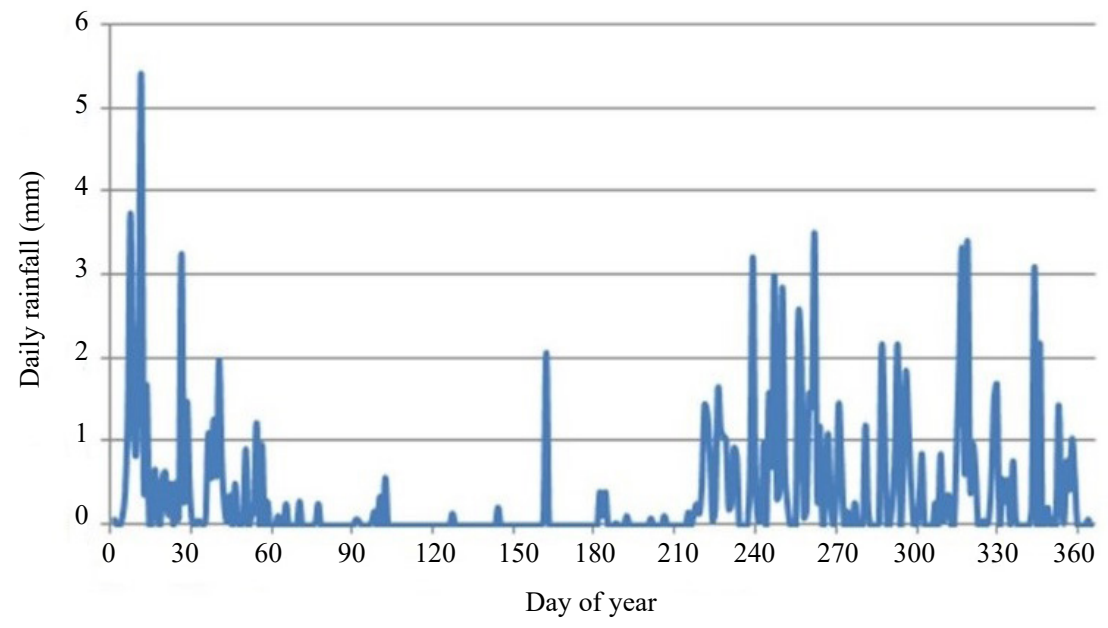

Figure 2. Average daily rainfall distribution in Varamin for seven years

\subsection{The selection of LID techniques}

After the initial investigation of more than 21 LID practices based on reviewed LID manuals, nine suitable techniques were selected for hot and arid areas with a low slope. The main effective basin factors for the selection of adequate LID techniques were discussed in this section. For a more detailed investigation, effective quality parameters need to be quantified based on available resources and guidelines [17,18,32,37-40]. Appropriate LID techniques were selected according to the project objectives, capabilities, and limitations of the study area. Reduction in the peak and volume of runoff and improvement of stormwater quality were the main objectives of the utilization of LID techniques.

Given the low annual rainfall, water conservation is also one of the influential factors that should be considered. Basin slope, climate, groundwater depth, operation and maintenance of existing facilities, and cost are among other factors that influence the selection of appropriate techniques. The most significant factors that influence the LID techniques are as listed in Table 1.

Each of the influential factors was scored according to their importance and impact. LID techniques were scored 1 (low), 3 (average), and 5 (top) for their impact. Additionally, they were scored 0 (inappropriate), 2 (weak), 4 (average), 6 (good), and 8 (top) for their effectiveness. 
Table 1. The most significant factors in the selection of LID techniques

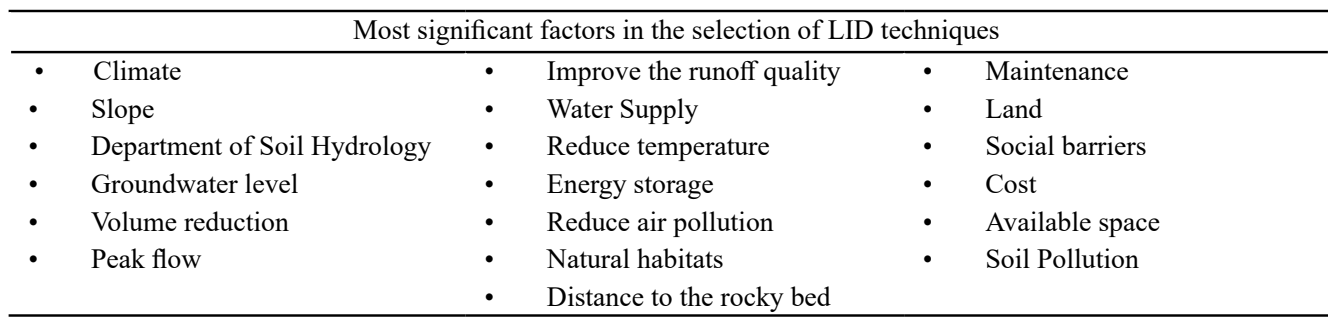

Then, a comprehensive investigation was conducted to collect and categorize criteria and recommendations based on 10 LID manuals, which included the Army LID Technical User Guide [32], Low Impact Development Standards Manual [40], Low Impact Development Best Management Practices Design Guide [38], Low Impact Development, Planning and Design Guide [39], Evaluation of Best Management Practices for Highway Runoff Control [41], Stormwater BMP Design Supplement for Cold Climate [42], California Stormwater BMP Handbook [43], Stormwater Management and Design Guidance Manual [44], Stormwater Best Management Practices Manual [45] and Low Impact Development, Design Guidance Manual [46].

Table 2 shows the scoring results of different LID techniques in the study area. These results were also discussed with experienced LID experts and stakeholders to enhance and assess the final scoring of the techniques, as shown in Figure 3.

Table 2. LID techniques scores based on different factors that influence the study area

\begin{tabular}{|c|c|c|c|c|c|c|c|c|c|c|}
\hline Benchmarks & $\begin{array}{l}\text { Bioretention } \\
\text { (infiltration) }\end{array}$ & $\begin{array}{c}\text { Permeable } \\
\text { pavement }\end{array}$ & $\begin{array}{l}\text { Vegetated } \\
\text { swale }\end{array}$ & $\begin{array}{c}\text { Rainwater } \\
\text { harvesting } \\
\text { system }\end{array}$ & $\begin{array}{l}\text { Vegetative } \\
\text { filter strips }\end{array}$ & Green roof & Dry well & $\begin{array}{l}\text { Infiltration } \\
\text { basin }\end{array}$ & $\begin{array}{l}\text { Infiltration } \\
\text { trenches }\end{array}$ & $\begin{array}{l}\text { Impact } \\
\text { factor }\end{array}$ \\
\hline Climate & 5 & 5 & 3 & 8 & 4 & 1 & 4 & 4 & 3 & 5 \\
\hline Slope & 8 & 8 & 8 & 8 & 6 & 8 & 6 & 8 & 6 & 1 \\
\hline $\begin{array}{l}\text { Hydrologic } \\
\text { soil group }\end{array}$ & 6 & 4 & 6 & 8 & 4 & 8 & 2 & 2 & 4 & 5 \\
\hline $\begin{array}{l}\text { Size } \\
\text { reduction }\end{array}$ & 8 & 8 & 3 & 6 & 4 & 2 & 4 & 8 & 8 & 3 \\
\hline Peak flow & 8 & 8 & 2 & 3 & 2 & 8 & 2 & 8 & 2 & 4 \\
\hline $\begin{array}{l}\text { Groundwater } \\
\text { recharge }\end{array}$ & 8 & 8 & 2 & 2 & 2 & 2 & 4 & 8 & 4 & 5 \\
\hline $\begin{array}{l}\text { Runoff } \\
\text { quality }\end{array}$ & 8 & 6 & 6 & 6 & 6 & 6 & 6 & 8 & 6 & 3 \\
\hline Reuse & 4 & 4 & 4 & 8 & 4 & 2 & 4 & 4 & 4 & 5 \\
\hline $\begin{array}{c}\text { Reduce } \\
\text { temperature }\end{array}$ & 6 & 2 & 6 & 2 & 6 & 6 & 2 & 2 & 2 & 2 \\
\hline $\begin{array}{l}\text { Reduce air } \\
\text { pollution }\end{array}$ & 4 & 1 & 4 & 1 & 1 & 4 & 1 & 1 & 1 & 1 \\
\hline $\begin{array}{l}\text { Aesthetic } \\
\text { criteria }\end{array}$ & 8 & 2 & 4 & 2 & 4 & 8 & 2 & 2 & 2 & 3 \\
\hline Maintenance & 6 & 2 & 6 & 6 & 4 & 3 & 6 & 2 & 6 & 5 \\
\hline $\begin{array}{c}\text { Social } \\
\text { barriers }\end{array}$ & 4 & 2 & 4 & 8 & 4 & 2 & 8 & 4 & 4 & 5 \\
\hline Land & 3 & 3 & 3 & 8 & 4 & 4 & 6 & 3 & 4 & 5 \\
\hline Cost & 4 & 4 & 4 & 6 & 4 & 2 & 4 & 3 & 4 & 5 \\
\hline Total & 328 & 261 & 231 & 337 & 219 & 224 & 245 & 265 & 240 & 456 \\
\hline
\end{tabular}




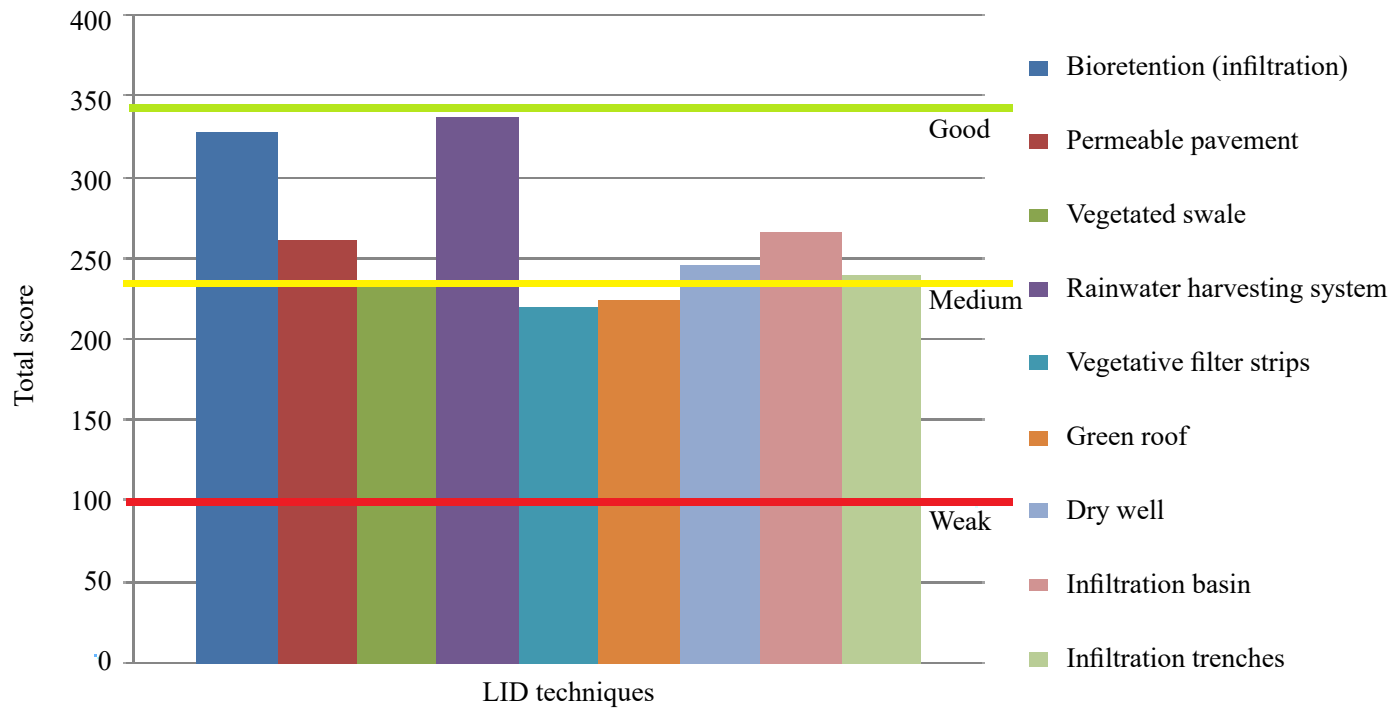

Figure 3. Total scores of LID techniques based on different factors that influence the study area

The finding highlighted that the performance of rainwater harvesting systems is reasonably good in this climate condition. Consequently, the performance of the bioretention and permeable pavement showed a number of positive effects on the control and management of stormwater in the basin. Therefore, in the following sections, the effectiveness of rainwater harvesting systems, bioretention and permeable pavement were evaluated using the SWMM model.

\subsection{Model development}

Geographic information system (GIS) was used to determine the physiographical and morphological characteristics of the basin. This information was required for the modeling of the surface water collection network. The surface geometry was extracted, and its digital elevation model (DEM) layer was achieved by using the topographic map of Varamin city. The Google Earth maps were georeferenced in the GIS environment using ArcGIS software in order to obtain the channel lengths. Based on Figure 4, the area was divided into 133 subbasins with 4 main outlets which drained into the downstream channel basin. As the main surface runoff flow of the basin discharged from outlet number 35 , the main focus was given to the simulation results of this node. The results of outlet number 3 , which discharged the runoff of a small subbasin with a low-density population, were also highlighted.

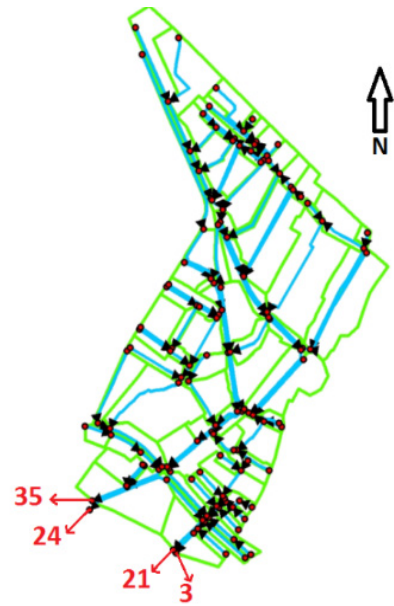

Figure 4. View of the catchment area in GIS software 
The land used was determined using Google Earth images. The runoff coefficient, curve number, and site imperviousness percent were calculated for each subbasin [47]. The mean values of hydrological characteristics for different zones of the basin are as listed in Table S2 in Appendix. The average slope of each subbasin and the altitude of each node were obtained from GIS. Imperviousness is a sensitive parameter in the hydrological classification of a basin, which lies in the range of 5\% for undeveloped areas up to $95 \%$ for high-density commercial areas and about 85 to $95 \%$ for very dense residential areas [25].

Since the Varamin weather station only records 24-hour rainfall data, the calculations of intensity, duration, and frequency (IDF) curves were required. These curves were extracted by using the Ghahreman equation as shown in Figure 5 [48]. Figures 6 and 7 show the distribution of rainfall patterns using the alternating block method in Varamin with a 2 and 5-year return period respectively.

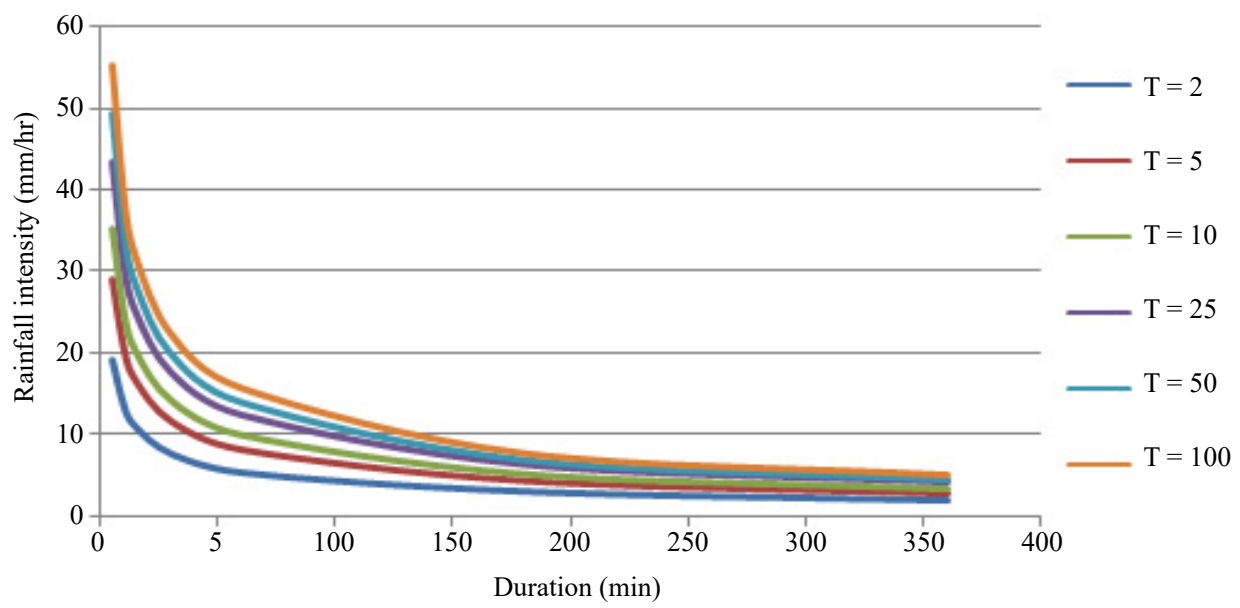

Figure 5. IDF Curves diagram

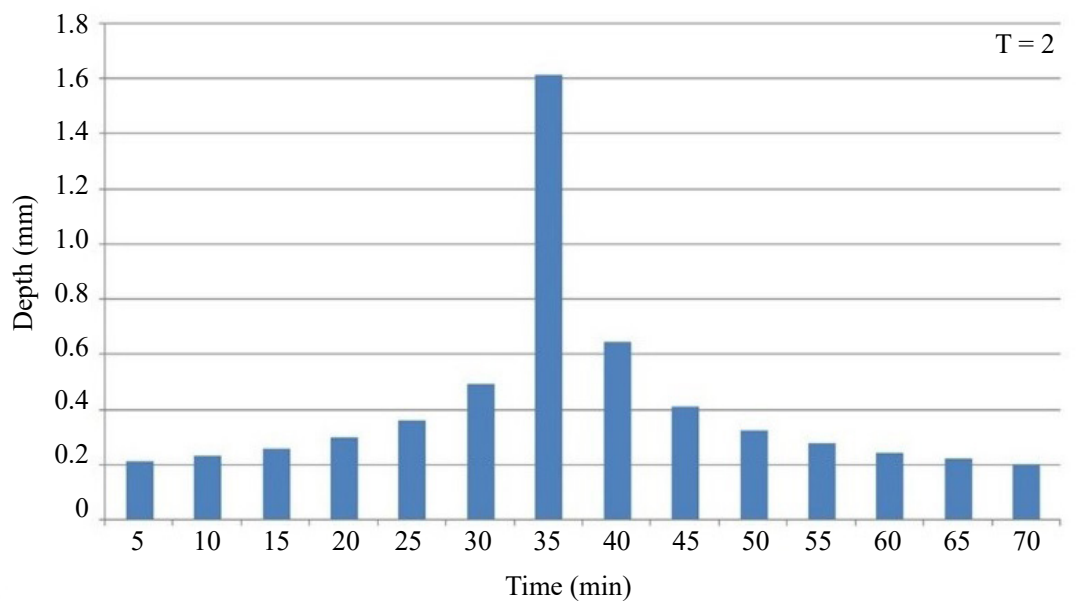

Figure 6. Distribution of rainfall pattern in Varamin with 2-year return period 


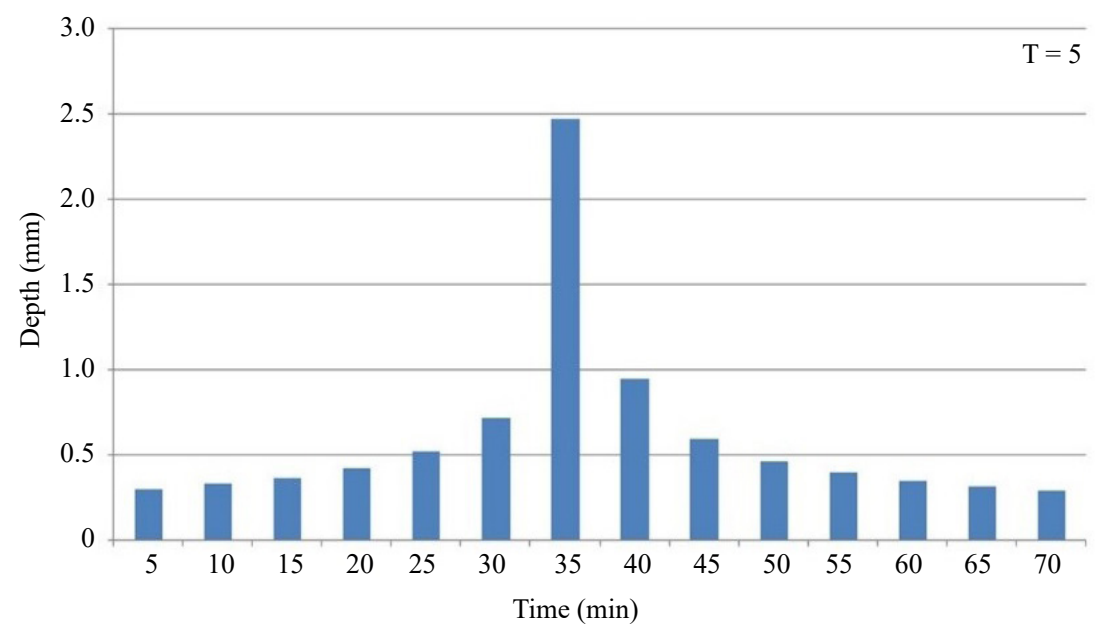

Figure 7. Distribution of rainfall pattern in Varamin with 5-year return period

The United States Environmental Protection Agency (EPA) SWMM is a dynamic rainfall-runoff simulation model. It is used for single event and long-term (continuous) simulation of runoff quantity and quality from primarily urban areas [49]. The capability of modeling LID has been added to this model. After providing basic information, SWMM was used to model the rainfall-runoff system in the study area. For this study, Autodesk Storm and Sanitary Analysis (ASSA) software was applied as a data exchange interface between the GIS and SWMM.

Manning's roughness coefficient was considered at 0.13 for permeable areas and 0.12 for impermeable areas. The depression storage depth was assumed at 1.7 and 5.08 for permeable and impermeable areas. In this study, the average channel length was $61.50 \mathrm{~m}$ and the average basin width was $119.18 \mathrm{~m}$. In the simulation, the Horton equation was used for infiltration as follows:

$$
f=f_{c}+\left(f_{0}-f_{c}\right) \mathrm{e}^{-k t}
$$

In this empirical formula, infiltration starts at a constant rate $f_{0}$, and decreases exponentially with time $t$. When the soil saturation level reaches a certain value, the rate of infiltration will settle to the final rate $f_{C}$, and $k$ is also a constant. These values can be obtained by observing the permeability of the soil and relevant information. In this study, the decay constant of 4.5 , the highest penetration rate of $200 \mathrm{~mm} /$ hour, and the lowest penetration rate of $20 \mathrm{~mm} / \mathrm{hour}$ were considered [50].

According to the Colorado Manual, the most important pollutant in urban runoff is total suspended solids (TSS). If water passes through a filter, colloidal and solutions will also pass through the filter, but particles larger than micron will remain on the filter. These particles are known as TSS and they absorb a significant part of the pollution in the water, thereby playing an important role in contaminant transport in the urban environment. The calculation of the amount of these materials and their elimination or reduction is the most important task in municipal areas. Thus, in the present study, only TSS was considered. In addition, a small amount of $10 \mathrm{mg} / \mathrm{liter}$ of TSS was assumed in rainwater [25].

Thus, we used an exponential curve with parameters $C_{1}$ (maximum build-up) and $C_{2}$ (build-up rate constant) to represent the build-up rate $B$ as a function of time $t$. The $C_{1}$ and $C_{2}$ values are 0.19 and $0.5 \mathrm{~kg} / \mathrm{m}$ for residential areas and 0.22 and $0.5 \mathrm{~kg} / \mathrm{m}$ for underdeveloped areas, respectively.

$$
B=C_{1}\left(1-\mathrm{e}^{-C_{2} t}\right)
$$

In this study, the event mean concentration (EMC) method was used to simulate the wash off. An estimation of the EMCs can be obtained from the Nationwide Urban Runoff Program (NURP), conducted by the EPA. 


$$
W=C_{1} \mathrm{Q}^{C_{2}}
$$

In this equation, $W$ is the rate of pollutants washed off per time (kg/hour) and $Q$ is the runoff flow discharge [49]. The wash-off exponent $C_{2}$ is equal to 1 and the value of $C_{1}$ in residential areas is assumed to be 200 .

The model was performed for rainfall-runoff, flow routing, and water quality simulation. To calibrate the model, the depth of the channel in 2 critical nodes (node 56 and 30) was recorded during the rainfall on November 22, 2013. The rainfall statistics were also collected from the Varamin Meteorology Department. The recorded values were in reasonable agreement by a $16 \%$ discrepancy. Flooded regions in the study area were also determined from model simulation. The same information was also obtained from the office of municipal services. The coincidence in flooded regions between observed and simulated results is reasonably comparable in more than $80 \%$ of the events. The average surface area of the roofs for each selected area was calculated to determine the volume and the number of rainwater reservoir tanks for domestic green spaces. The study area is highly dense, so the area of roof buildings is about $56 \%$, thereby intensifying the efficiency of rainwater harvesting techniques.

Some basic assumptions were also made to calculate the volume of tanks. It was assumed that in Varamin, the stored water is only used for domestic gardens, where the area of every garden is $2 \%$ of the roof area, and the maximum water demand is 12 liters/day for green spaces. The reservoir tanks should be full at the beginning of the 5-month dry period. Their volume is determined to respond to the water demands during the dry periods. The container volume is calculated by the following equation [51]:

$$
Q=\phi \cdot R(t) \cdot A
$$

where $Q$ is the volume of harvested rainwater (liter), $\varphi$ is the runoff coefficient, $R(t)$ is the daily rainfall (mm), and $A$ is the rainwater harvesting catchment area $\left(\mathrm{m}^{2}\right)$. Rainfall and water demand are very heterogeneous in Varamin. Therefore, the volume of tanks is not on the basis of annual rainfall and demand. However, they should be full at the beginning of the dry period and provide enough supply to respond to the demands of that period.

Characteristics of bioretention were imported into the model with respect to the guidelines and specific conditions of the study area. Three sets of data are required to simulate bioretention. These include the characteristics of the soil layer, the storage and underdrain layers, and permeable pavement. Soil layer characteristics were determined based on soil conditions and the relevant information [49]. The characteristics of the storage and underdrain layers were determined on the basis of basin specifications. The layout of permeable pavement was determined and imported into the model based on available guidelines [52].

\subsection{Model scenarios}

In this study, three scenarios of rainwater tanks, bioretention cells, and permeable pavement were considered as effective LID techniques in this semi-arid area. The first scenario was applied in three phases, including the north region, north plus central regions, and north plus central and south regions.

\subsubsection{Scenario 1: Rainwater tanks}

Phase 1 - North region: In the first phase of this scenario, rainwater tanks were only applied to the buildings in the northern area. According to the calculations, the storage tanks were assumed to be 2,000, 3,000, 3,500, 4,000, and 4,500 liters with a radius of $0.75 \mathrm{~m}$, and 5,000,5,500 and 6,500 liters with a radius of $1 \mathrm{~m}$. Also, storage tanks with the volumes of 7,000, 7,500, and 10,000 liters were considered for office, business, and educational buildings. A total of about 4,542 rainwater tanks were needed within the northern region.

Phase 2- North plus central regions: In the second phase, central basins were equipped with rainwater tanks. Storage tanks in this area were assumed to be 3,000,3,500, 4,000, and 4,500 liters with a radius of $0.75 \mathrm{~m}$ and 5,500 liters with a radius of $1 \mathrm{~m}$. Therefore, a total of 1,680 tanks were needed in the central area. 
Phase 3- North plus central and south regions: In the third phase, southern basins were equipped with rainwater tanks. The catchment area of $570 \mathrm{~m}^{2}$ required a 20,000 liters storage. 10,000 liters tanks were used for such areas. Tanks with a radius of $0.75,1$ and $1.5 \mathrm{~m}$ and a volume of 5,000,5,000 to 10,000, and more than 5,000 respectively were introduced. Therefore, a total of 3,313 tanks were needed in the southern area.

\subsubsection{Scenario 2: Bioretention}

About $9.4 \%$ of the study areas have been allocated to green parks, squares, and boulevards (almost 19 hectares). $27 \%$ of green lands in the areas are equipped with bioretention (5.16 hectares) with respect to the feasibility of the bioretention and the basins with more than $15 \%$ impermeable area. Figure 8 shows the bioretention pattern in the study area.

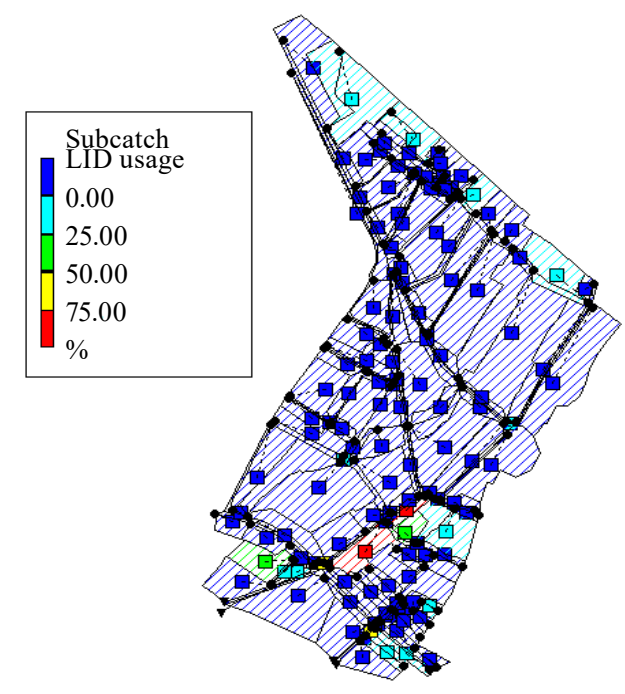

Figure 8. Bioretention layout pattern in the study area

\subsubsection{Scenario 3: Permeable pavement}

Approximately $33.3 \%$ of the study area is covered with walkways, streets, and impermeable pavements (approximately 67 hectares). The permeable pavement system is suggested for the main streets in the area. Therefore, it was applied to the Bahonar, Imam Khomeini, and Hemat boulevards, along with the Shohada, Beheshti, Taleghani and Masjed Jame streets. Figure 9 shows the implementation of permeable pavements pattern in the study area. 


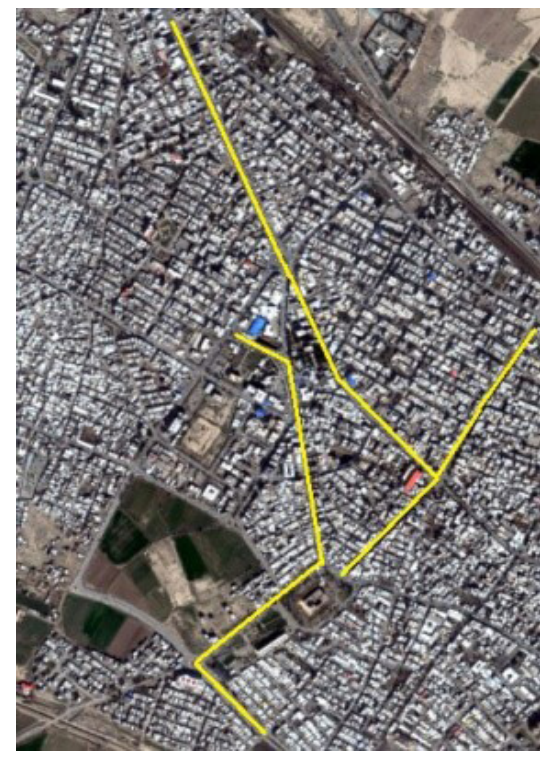

Figure 9. Permeable pavement layout pattern in the study area

\section{Results and discussion}

The reduction percentage of the hydraulic parameters of the scenarios for 2 and 5 -year return periods are as shown in Table 3 to 6 . The hydraulic parameters included in these tables are TSS, mean and peak discharge, total runoff and total volume.

Table 3. Reduction percentage of hydraulic parameters at node 35 for 2-year return period

\begin{tabular}{|c|c|c|c|c|c|}
\hline \multirow[b]{2}{*}{ Parameter } & \multicolumn{5}{|c|}{ Scenario - Reduction percentage (\%) } \\
\hline & $\begin{array}{c}\text { First } \\
\text { (phase 1) }\end{array}$ & $\begin{array}{c}\text { First } \\
\text { (phase 2) }\end{array}$ & $\begin{array}{c}\text { First } \\
\text { (phase 3) }\end{array}$ & Second & Third \\
\hline Average discharge & 6.12 & 11.83 & 31.2 & 5.71 & 4.89 \\
\hline Peak discharge & 0.22 & 1.82 & 12.7 & 3.41 & 0.20 \\
\hline Total volume & 17.64 & 24.67 & 40.71 & 7.08 & 8.30 \\
\hline Total runoff & 17.37 & 24.59 & 40.77 & 7.31 & 3.85 \\
\hline TSS & 16.84 & 22.69 & 37.91 & 7.12 & 3.59 \\
\hline
\end{tabular}

Table 4. Reduction percentage of hydraulic parameters at node 35 for 5-year return period

\begin{tabular}{cccccc}
\hline \multirow{2}{*}{ Parameter } & First & First & First & Second & Third \\
& (phase 1) & (phase 2) & (phase 3) & & 3.58 \\
\hline Average discharge & 2.15 & 3.94 & 18.63 & 5.37 & 0 \\
Peak discharge & 0 & 0.62 & 12.29 & 6.25 & 3.13 \\
Total volume & 15.66 & 19.70 & 31.42 & 6.62 & 3.47 \\
Total runoff & 7.65 & 9.85 & 23.70 & 7.54 & 3.53 \\
TSS & 9.20 & 11.73 & 24.29 & & \\
\hline
\end{tabular}


Table 5. Reduction percentage of hydraulic parameters at node 3 for 2 -year return period

\begin{tabular}{cccc}
\hline \multirow{2}{*}{ Parameter } & \multicolumn{3}{c}{ Scenario - Reduction percentage (\%) } \\
& $\begin{array}{c}\text { First } \\
\text { (phase 3) }\end{array}$ & Second & Third \\
\hline Average discharge & 56.52 & 34.78 & 21.73 \\
Peak discharge & 61.16 & 36.89 & 21.35 \\
Total volume & 57.03 & 33.70 & 19.25 \\
Total runoff & 56.86 & 33.93 & 19.32 \\
TSS & 56.78 & 33.92 & 19.11 \\
\hline
\end{tabular}

Table 6. Reduction percentage of hydraulic parameters at node 3 for 5-year return period

\begin{tabular}{cccc}
\hline \multirow{2}{*}{ Parameter } & \multicolumn{3}{c}{ Scenario - Reduction percentage (\%) } \\
& $\begin{array}{c}\text { First } \\
\text { (phase 3) }\end{array}$ & Second & Third \\
\hline Average discharge & 57.50 & 32.50 & 20.00 \\
Peak discharge & 62.50 & 37.00 & 21.50 \\
Total volume & 56.84 & 33.41 & 19.20 \\
Total runoff & 56.72 & 33.85 & 19.28 \\
TSS & 56.47 & 33.57 & 18.87 \\
\hline
\end{tabular}

The results show that the best performance is provided by the implementation of the third phase of the first scenario and the application of rainwater harvesting tanks across the study area. Significant changes cannot be seen in the drainage 35 by converting $27 \%$ of green space ( 5 hectares) to bioretention in the second scenario. In drainage 3 , the implementation of the first and second phases of the first scenario caused no effect, while the implementation of the second scenario reduced the total volume to $33 \%$.

Besides, changing the design return period for rainfall from 2 to 5 years caused a smaller percentage in drainage 3 compared to that of drainage 35. Implementation of permeable pavement has less effect on the hydraulic load of output flow compared to all scenarios (even the first phase).

\section{Conclusion}

During the planning, designing, and constructing of the LID techniques, regional characteristics and project objectives should be considered. The characteristics of hot and arid areas may affect the performance of LID techniques. Thus, this study aimed to provide an improved understanding of the applicability and effectiveness of LID techniques in the arid regions. The main goal is to manage urban stormwater by evaluating the applicability of different LID techniques to obtain the maximum benefit at minimum cost as the intrinsic objective of the optimization process.

The influential factors were presented and weighted according to the study area characteristics and the relevant manuals. Then, the three high-ranked LID techniques were modeled by the SWMM for examination and validation purposes. The rainwater harvesting systems were found to have the greatest impact on the surface water collection system in terms of both stormwater quality and quantity management. In addition, it saves water for irrigation and domestic cleaning. Three important conclusions can be made here:

1. Rainwater harvesting systems are the most applicable LID techniques in arid and hot areas with limited rain.

- Using rainwater for landscaping and interior washing saves water and reduces pressure on the urban water supply network, and it provides for the water demands of home gardens during the dry period (5 months of the year) and the needs for domestic cleaning in the other months.

- In areas with a high density of buildings, in addition to reducing the occupied areas, tanks collect more rainwater. Consequently, less runoff enters the surface water network, and problems with surface water 
collection systems are reduced (especially in the 2 and 5 -year return periods).

2. Changing the whole urban landscape to bioretention is not recommended due to the high cost, maintenance problems, and lack of effectiveness in reducing runoff. However, the limited use of this technique in proper land use and less dense urban areas that are faced with waterlogging problems can locally reduce the surface water collection network issues. Besides, using plants adapted to the climate saves water consumption and costs, and improves the runoff quality.

3. The application of permeable pavement systems may not be more appropriate than rainwater tanks and bioretention due to less impact on waterlogging reduction, quality of surface water collection system, and maintenance and running costs. However, in areas where it is impossible to use bioretention due to lack of green space, the application of these techniques can be useful to increase the permeability of the basin.

Note that LID practices can attenuate the dramatic effects of urbanization and consequently enhance resiliency in response to climate change [16]. Thus, future research should consider the effects of climate change on the applicability of LID techniques in arid regions. The improved understanding of how climate change affects the hydrologic behavior and effectiveness of LID techniques is vital to increasing the adoption and reliability of LIDs for stormwater runoff management and other co-benefits [53].

\section{Acknowledgement}

We thank anonymous reviewers and editors for their critical and constructive comments on this paper.

\section{References}

[1] Zhu Z, Chen Z, Chen X, Yu G. An assessment of the hydrologic effectiveness of low impact development (LID) practices for managing runoff with different objectives. Journal of environmental management. 2019; 231: 504514. Available from: https://doi.org/10.1016/j.jenvman.2018.10.046.

[2] Jiang Y, Yuan Y, Piza H. A review of applicability and effectiveness of low impact development/green infrastructure practices in arid/semi-arid United States. Environments. 2015; 2(2): 221-249. Available from: https://doi. org/10.3390/environments2020221.

[3] Huang K, Li X, Liu X, Seto KC. Projecting global urban land expansion and heat island intensification through 2050. Environmental Research Letters. 2019; 14(11): 114037. Available from: https://doi.org/10.1088/1748-9326/ $\mathrm{ab} 4 \mathrm{~b} 71$.

[4] Kaloustian N, Diab Y. Effects of urbanization on the urban heat island in Beirut. Urban Climate. 2015; 14: 154165. Available from: https://doi.org/10.1016/j.uclim.2015.06.004.

[5] Liu X, Huang Y, Xu X, Li X, Li X, Ciais P, Lin P, Gong K, Ziegler AD, Chen A, Gong P. High-spatiotemporalresolution mapping of global urban change from 1985 to 2015. Nature Sustainability. 2020; 3(7): $564-570$. Available from: https://doi.org/10.1038/s41893-020-0521-x.

[6] Heidari H, Arabi M, Warziniack T, Sharvelle S. Effects of Urban Development Patterns on Municipal Water Shortage. Frontiers in Water. 2021; 3: 1-11. Available from: https://doi.org/10.3389/frwa.2021.694817.

[7] Sanchez GM, Terando A, Smith JW, García AM, Wagner CR, Meentemeyer RK. Forecasting water demand across a rapidly urbanizing region. Science of the Total Environment. 2020; 730: 139050. Available from: https://doi. org/10.1016/j.scitotenv.2020.139050.

[8] Hao Z, Singh VP, Xia Y. Seasonal drought prediction: advances, challenges, and future prospects. Reviews of Geophysics. 2018; 56(1): 108-141. Available from: https://doi.org/10.1002/2016RG000549.

[9] Brown TC, Foti R, Ramirez JA. Projected freshwater withdrawals in the United States under a changing climate. Water Resources Research. 2013; 49(3): 1259-1276. Available from: https://doi.org/10.1002/wrcr.20076.

[10] Heidari H, Arabi M, Ghanbari M, Warziniack T. A probabilistic approach for characterization of sub-annual socioeconomic drought intensity-duration-frequency (IDF) relationships in a changing environment. Water. 2020; 12(6): 1522. Available from: https://doi.org/10.3390/w12061522.

[11] Heidari H, Arabi M, Warziniack T, Kao SC. Shifts in hydroclimatology of US megaregions in response to 
climate change. Environmental Research Communications. 2021; 3(6); 065002. Available from: https://doi. org/10.1088/2515-7620/ac0617.

[12] Li W, Hai X, Han L, Mao J, Tian M. Does urbanization intensify regional water scarcity? Evidence and implications from a megaregion of China. Journal of Cleaner Production. 2020; 244: 118592. Available from: https://doi.org/10.1016/j.jclepro.2019.118592.

[13] Bouziotas D, Rozos E, Makropoulos C. Water and the city: exploring links between urban growth and water demand management. Journal of Hydroinformatics. 2015; 17(2): 176-192. Available from: https://doi.org/10.2166/ hydro.2014.053.

[14] Lizárraga-Mendiola L, Vázquez-Rodríguez GA, Lucho-Constantino CA, Bigurra-Alzati CA, Beltrán-Hernández RI, Ortiz-Hernández JE, López-León LD. Hydrological design of two low-impact development techniques in a semi-arid climate zone of Central Mexico. Water. 2017; 9(8): 561. Available from: https://doi.org/10.3390/ w9080561.

[15] Batalini de Macedo M, Nóbrega Gomes Júnior M, Pereira de Oliveira TR, H. Giacomoni M, Imani M, Zhang K, Ambrogi Ferreira do Lago C, Mendiondo EM. Low Impact Development practices in the context of United Nations Sustainable Development Goals: A new concept, lessons learned and challenges. Critical Reviews in Environmental Science and Technology. 2021: 1-44. Available from: https://doi.org/10.1080/10643389.2021.1886889.

[16] Islam A, Hassini S, El-Dakhakhni W. A systematic bibliometric review on optimization and resilience of a stormwater management approach: Low-impact-development. Journal of Hydrology. 2021; 599: 126457. Available from: https://doi.org/10.1016/j.jhydrol.2021.126457.

[17] Ghodsi SH, Zahmatkesh Z, Goharian E, Kerachian R, Zhu Z. Optimal design of low impact development practices in response to climate change. Journal of Hydrology. 2020; 580: 124266. Available from: https://doi.org/10.1016/ j.jhydrol.2019.124266.

[18] Bahrami M, Bozorg-Haddad O, Loáiciga HA. Optimizing stormwater low-impact development strategies in an urban watershed considering sensitivity and uncertainty. Environmental monitoring and assessment. 2019; 191(6): 1-4. Available from: https://doi.org/10.1007/s10661-019-7488-y.

[19] Li J, Deng C, Li Y, Li Y, Song J. Comprehensive benefit evaluation system for low-impact development of urban stormwater management measures. Water Resources Management. 2017; 31(15): 4745-4758. Available from: https://doi.org/10.1007/s11269-017-1776-5.

[20] Seo M, Jaber F, Srinivasan R, Jeong J. Evaluating the impact of low impact development (LID) practices on water quantity and quality under different development designs using SWAT. Water. 2017; 9(3): 193. Available from: https://doi.org/10.3390/w9030193.

[21] Rezaei AR, Ismail Z, Niksokhan MH, Dayarian MA, Ramli AH, Shirazi SM. A quantity-quality model to assess the effects of source control stormwater management on hydrology and water quality at the catchment scale. Water. 2019; 11(7): 1415. Available from: https://doi.org/10.3390/w11071415.

[22] Bigurra-Alzati CA, Ortiz-Gómez R, Vázquez-Rodríguez GA, López-León LD, Lizárraga-Mendiola L. Water Conservation and Green Infrastructure Adaptations to Reduce Water Scarcity for Residential Areas with SemiArid Climate: Mineral de la Reforma, Mexico. Water. 2021; 13(1): 45. Available from: https://doi.org/10.3390/ w13010045.

[23] Hashemi MS, Tajrishy M, Jalilvand E. The Impact of Pavement Permeability on Time of Concentration in a Small Urban Watershed with a Semi-Arid Climate. Water Resources Management. 2020; 34(9): 2969-2988. Available from: https://doi.org/10.1007/s11269-020-02596-3.

[24] Eshkevardalili S, Motawef S, Alipoori E. Water source planning in arid zones using low impact development (LID) approach (case study: The Basin of Salt Lake and Central Desert, Iran). Ukrainian Journal of Ecology. 2018; 8(3): 293-303.

[25] Gironás J, Roesner LA, Davis J, Rossman LA, Supply W. Storm water management model applications manual. Cincinnati, OH: National Risk Management Research Laboratory, Office of Research and Development, US Environmental Protection Agency; 2009.

[26] Heidari H, Arabi M, Warziniack T, Kao SC. Assessing shifts in regional hydroclimatic conditions of US river basins in response to climate change over the 21st century. Earth's Future. 2020; 8(10): 1-14. Available from: https://doi.org/10.1029/2020EF001657.

[27] Heidari H, Warziniack T, Brown TC, Arabi M. Impacts of climate change on hydroclimatic conditions of US national forests and grasslands. Forests. 2021;12(2): 139. Available from: https://doi.org/10.3390/f12020139.

[28] Ghanbari M, Arabi M, Kao SC, Obeysekera J, Sweet W. Climate Change and Changes in Compound CoastalRiverine Flooding Hazard Along the US Coasts. Earth's Future. 2021; 9: e2021EF002055. Available from: https:// 
doi.org/10.1029/2021EF002055.

[29] Ghanbari M, Arabi M, Obeysekera J, Sweet W. A coherent statistical model for coastal flood frequency analysis under nonstationary sea level conditions. Earth's Future. 2019; 7(2): 162-177. Available from: https://doi. org/10.1029/2018EF001089.

[30] Carlson W, Fitzpatrick E, Flanagan E, Kirschbaum R, Williams H, Zickler L. Eastern Washington Low Impact Development Guidance Manual. Department of Ecology State of Washington. 2013.

[31] Colorado Water Conservation Board. Holistic Approach to Sustainable Water Management in Northwest Douglas County. Colorado: Leonard Rice Engineers, Inc; 2007.

[32] U.S. Army Corps of Engineers. Army Low Impact Development Technical User Guide. 2013. Available from: http://www.usace.army.mil/Portals/2/docs/Sustainability/Hydrology_LID/Army_LID_Technical_User_Guide_ January2013.pdf [Accessed 15th April 2021].

[33] LaBadie K. Identifying barriers to low impact development and green infrastructure in the Albuquerque Area. MS thesis. University of New Mexico; 2010. Available from: https://nmwrri.nmsu.edu/wp-content/uploads/2015/ research/rfp/studentgrants08/reports/LaBadie.pdf [Accessed 15th April 2021].

[34] Ahiablame LM, Engel BA, Chaubey I. Effectiveness of low impact development practices in two urbanized watersheds: Retrofitting with rain barrel/cistern and porous pavement. Journal of environmental management. 2013; 119: 151-161. Available from: https://doi.org/10.1016/j.jenvman.2013.01.019.

[35] Amin MT, Alazba AA, ElNesr MN. Adaptation of climate variability/extreme in arid environment of the Arabian peninsula by rainwater harvesting and management. International journal of environmental science and technology. 2013; 10(1): 27-36.

[36] El-Refaie GG, Farag HA, El-Baroudy IE. Impact of Arid Climatic Conditions on Engineered Wetland Design and Performance: Egypt Case Study. Nile Water Science \& Engineering Journal. 2010; 3(3); 100-111.

[37] Seo M, Jaber F, Srinivasan R. Evaluating various low-impact development scenarios for optimal design criteria development. Water. 2017; 9(4): 270. Available from: https://doi.org/10.3390/w9040270.

[38] City of Edmonton. Low Impact Development Best Management Practices Design Guide Edition 1.1. Alberta: City of Edmonton; 2014. p. 41-84. Available from: https://www.edmonton.ca/sites/default/files/public-files/assets/PDF/ LIDGuide.pdf [Accessed 15th April 2021].

[39] Credit Valley Conservation (CVC) and Toronto And Region Conservation (TRCA). Low Impact Development Stormwater Planning and Design Guide. CVC and TRCA. 2010. Available from: https://sustainabletechnologies. ca/app/uploads/2013/01/LID-SWM-Guide-v1.0_2010_1_no-appendices.pdf [Accessed 15th April 2021].

[40] County of Los Angeles Department of Public Works. Low Impact Development, Standards Manual. Los Angeles: County of Los Angeles; 2014.

[41] National Academies of Sciences, Engineering, and Medicine. Evaluation of Best Management Practices for Highway Runoff Control. Washington, DC: The National Academies Press; 2006. Available from: https://doi. org/10.17226/23211.

[42] Caraco D, Claytor RA. Stormwater BMP Design: Supplement for Cold Climates. Ellicot City, MD: US Environmental Protection Agency; 1997.

[43] California Stormwater Quality Association (CASQA). California Stormwater BMP Handbook. Menlo Park, CA: California Stormwater Quality Association; 2003.

[44] West Virginia Department of Environmental Protection. Sheet Flow to Vegetated Filter Strips and Conservation Areas. In: West Virginia Stormwater Management and Design Guidance Manual. West Virginia: Center for Watershed Protection, Inc.; 2012. p. SF1-SF24.

[45] Blick SA, Kelly F, Skupien JJ. Chapter 2: Low Impact Development Techniques. In: New Jersey Stormwater Best Management Practices Manual. New Jersey: Department of Environmental Protection; 2004. p. 2-1

[46] USKH Inc. Water Resources Group. Low Impact Development, Design Guidance Manual. Alaska: Watershed Management Services, Municipality of Anchorage; 2008.

[47] Mahab Ghods Consulting Engineering Co. Comprehensive Proposal for Surface Water Management of Tehran. 2011. Available from: http://www.mahabghodss.com [Accessed 15th April 2021].

[48] Ghahraman B, Abkhezr HR. Correction of the rainfall intensity-duration-frequency equations in Iran. Journal of Science And Technology of Agriculture and Natural Resources. 2004; 8(2): 1-3.

[49] Rossman LA. Storm water management model user's manual, version 5.0. Cincinnati: National Risk Management Research Laboratory, Office of Research and Development, US Environmental Protection Agency; 2010.

[50] Alizadeh A. Principles of applied hydrology. Mashhad: Emam Reza University; 2008.

[51] Palla A, Gnecco I, Lanza LG. Non-dimensional design parameters and performance assessment of rainwater 
harvesting systems. Journal of Hydrology. 2011; 401(1-2): 65-76.

[52] Korkealaakso J, Kuosa H, Niemeläinen E, Tikanmäki M. Review of pervious pavement dimensioning, hydrological models and their parameter needs. State-of-the-Art. Climate Adaptative Surface CLASS. Report number: VTT-R-08227-13, 2014. Available from: https://projectsites.vtt.fi/sites/class/www.vtt.fi/sites/class/en/Documents/ D4_1_CLASS_WP4_SOTA_Dimensioning_and_Models.pdf [Accessed 15th April 2021].

[53] Voter CB, Loheide SP. Climatic controls on the hydrologic effects of urban low impact development practices. Environmental Research Letters. 2021; 16(6): 064021. Available from: https://doi.org/10.1088/1748-9326/abfc06. 


\section{Appendix}

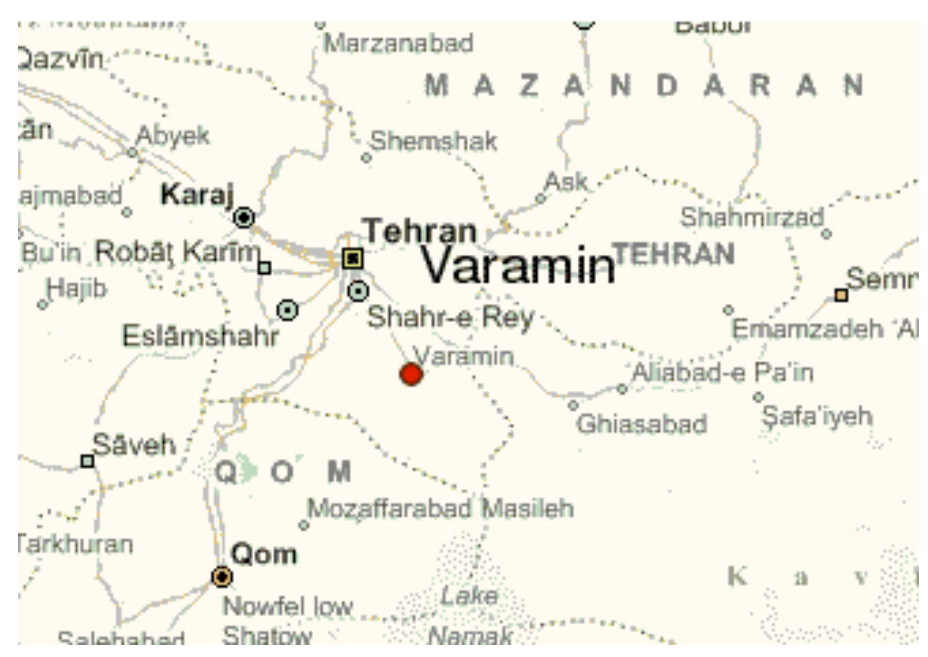

Figure S1. The location of Varamin city

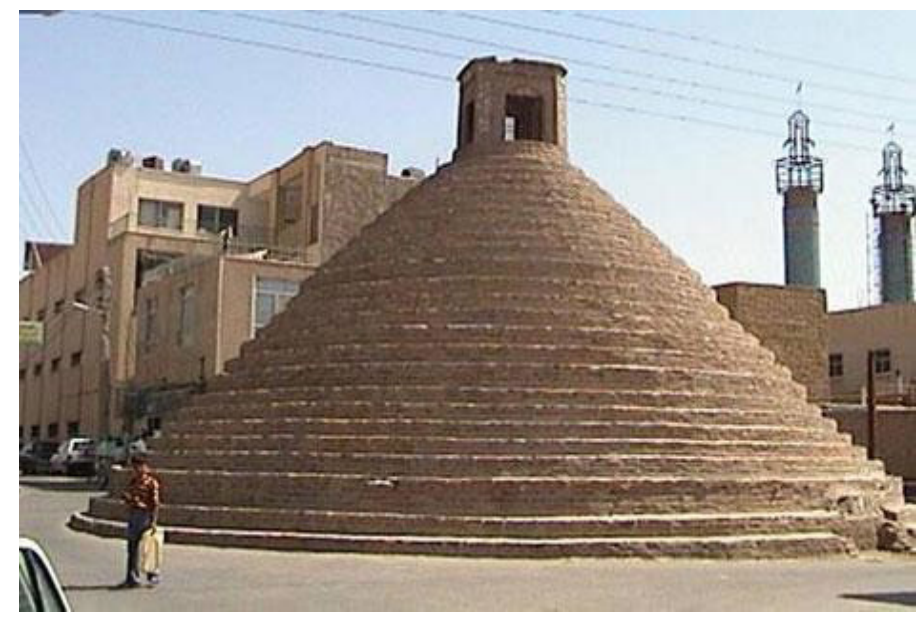

Figure S2. A view of an old Ab-Anbar in the study area 


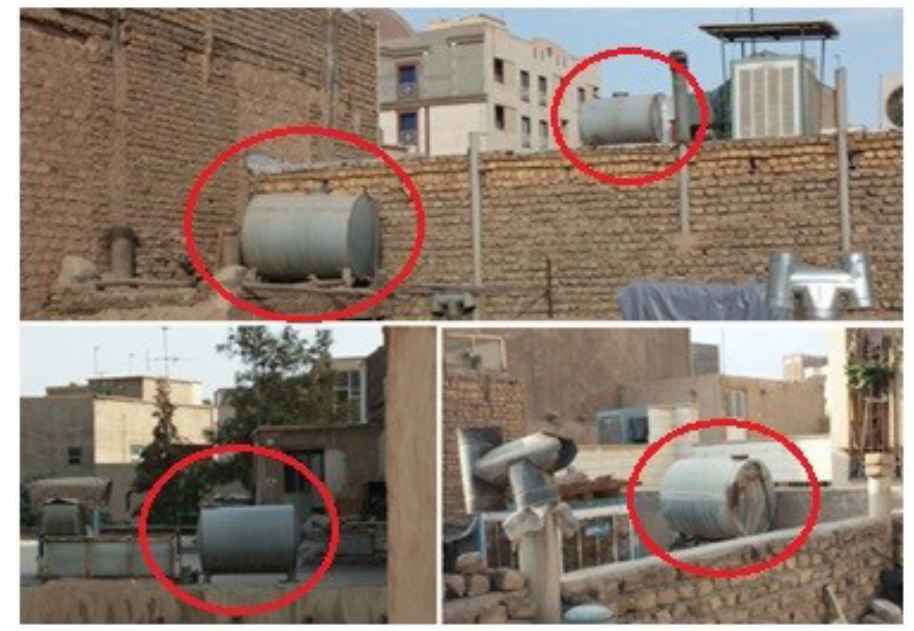

Figure S3. A view of water tanks on the roofs of the study area

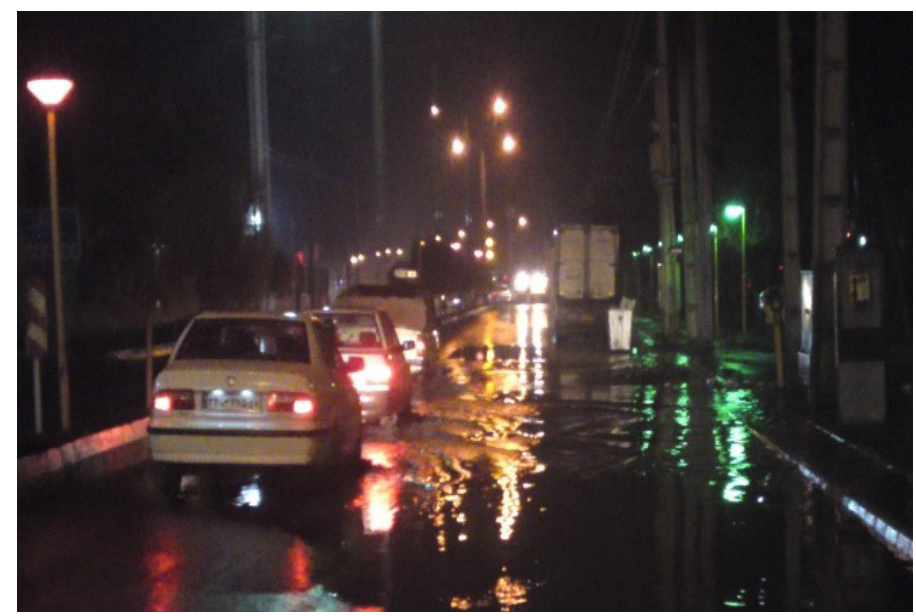

Figure S4. A view of water logging in the southern region

Table S1. Percentage of land use in the study area

\begin{tabular}{ccccc}
\hline Sub basin & Roof & Impermeable area & Green space & $\begin{array}{c}\text { Undeveloped } \\
\text { landscape }\end{array}$ \\
\hline Northern & $63.9 \%$ & $30.55 \%$ & $5.55 \%$ & $0 \%$ \\
Central & $63.1 \%$ & $32.60 \%$ & $3.40 \%$ & $0 \%$ \\
Southern & $42.0 \%$ & $36.60 \%$ & $18.40 \%$ & $3 \%$ \\
Average & $56.3 \%$ & $33.30 \%$ & $9.40 \%$ & $1 \%$ \\
\hline
\end{tabular}

Table S2. Details of existing hydrological basins

\begin{tabular}{cccc}
\hline Sub basin & Runoff coefficient & Runoff curve number & Percent impervious \\
\hline Northern & $89.45 \%$ & 89.36 & 0.70 \\
Central & $90.76 \%$ & 89.55 & 0.71 \\
Southern & $73.74 \%$ & 88.14 & 0.61 \\
Average & $84.65 \%$ & 89.02 & 0.67 \\
\hline
\end{tabular}

